УДК 377.3:001

DOI:

Володимир Кулішов, кандидат педагогічних наук, старший викладач кафедри методики професійної освіти та соціально-гуманітарних дисциплін Білочерківського інституту неперервної професійної освіти ДВНЗ

“Університет менеджменту освіти” НАПН України

\title{
ДЕЯКІ АСПЕКТИ СТАНОВЛЕННЯ ТА РОЗВИТКУ ПРОЕКТНОЇ ТЕХНОЛОГІЇ НАВЧАННЯ У СИСТЕМІ ПРОФЕСІЙНОЇ ПІДГОТОВКИ КВАЛІФІКОВАНИХ РОБІТНИКІВ
}

Стаття присвячена ретроспективному аналізу деяких аспектів становлення та розвитку технологіi проектного навчання у системі професійної підготовки кваліфікованих робітників. Автором здійснено спробу висвітлити досягнення зарубіжних та вітчизняних учених щзодо шляхів виникнення та способів реалізації проектної технології навчання в освітньо-виробничих умовах трудової та професійної підготовки підростаючого покоління. Окреслено можливості та перспективи проектної діяльності учнів закладів професійно-технічної освіти.

Ключові слова: професійно-технічна освіта; проектна технологія навчання; професійна підготовка; навчання через дію; засіб професіоналізації; моделювання; педагогіка співробітництва.

Jim. 14.

Volodymyr Kulishov, Ph.D.(Pedagogy), Senior Lecturer of the Methodology of Vocational Education and Social and Humanitarian Disciplines Department Bilotserkivsk Institute of Lifelong Professional Education State Higher Educational Establishment "University of Management Education" National Academy of Pedagogical Science of Ukraine

\section{SOME ASPECTS OF FORMATION AND DEVELOPMENT OF PROJECT TECHNOLOGY OF TEACHING IN THE PROFESSIONAL TRAINING SYSTEM OF QUALIFIED EMPLOYEES}

The article is devoted to the retrospective analysis of some aspects of formation and developmentof project technology of teaching in the system of professional training of qualified employees. The author attempts to highlight the achievements of foreign and domestic scientists as for the ways of occurrence and methods of implementing the project technology of teaching into the educational and production conditions of the labor and professional training of the young generation. The possibilities and perspectives of project activity of students of vocational education institutions are outlined.

The author noted that the project technology training has a long history. Its origins relate to the activities of Italian architectural schools of the 16th century as well as the educational activities of one of the ideologists of the working schools of John Locke.

At the beginning of the 20th century, the project training became particularly popular in the USA due to new activity approaches to the organization of teaching and production process. American educator and reformer John Dewey and his student professor of pedagogy William Kilpatrick are considered to be founders of project technology of teaching.

The author also describes the scientific contribution of domestic Ukrainian scientists and practitioners in the process of establishing and developing the project technology of education. In particular it is described the experience of implementing projects into pedagogical activity of A. Makarenko and $O$. Zaharenko.

The modern period of development of project technology of education is characterized by significant research on theoretical substantiation of technology, ways and means of its practical implementation in the educational process at all levels, description and justification of the stages of the project activity, typology of projects, the role of the teacher and the student in the organization of project training.

Keywords: vocational education; the project technology of teaching; the professional training; learning through action; the means of professionalization; modeling; pedagogy of cooperation.

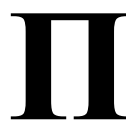
остановка проблеми. Сучасний розвиток вітчизняної освіти зумовлений досягненнями технологічного та науковотехнічного прогресуу всіх сферах життєдіяльності людини. Це стає ключовою точкою відліку якісних видозмін виробничого та суспільного характеру.
Створення, використання і подальший розвиток надскладних технологій, поширення комп'ютерної та інформаційної техніки зумовили перспективи принципово інших підходів до підготовки трудових ресурсів нового покоління, що визначаються процесами глобалізації, ринковими механізмами 


\section{ДЕЯКІ АСПЕКТИСТАНОВЛЕННЯТА РОЗВИТКУ ПРОЕКТНОӤ ТЕХНОЛОГІЇ НАВЧАННЯ У СИСТЕМІПРОФЕСІЙНОӤ ПІДГОТОВКИКВАЛІФІКОВАНИХ РОБІТНИКІВ}

економіки, потребами вітчизняного і світового ринків праці та потребами особистості в соціально-професійній підготовці.

Зазначені закономірності і тенденції мають безпосередній стосунок до системи вітчизняної професійно-технічної освіти, перед якою держава поставила стратегічно важливе завдання підготовкуконкурентоздатного, висококваліфікованого, “інтелектуалізованого” фахівця сучасного виробництва, який здатний:

- гнучко адаптуватися в мінливих життєвих умовах

- самостійно здобувати необхідні знання, вміло застосовувати їх на практиці для вирішення виникаючих проблем;

- творчо і критично мислити;

- вміти бачити виникаючі в реальній дійсності проблеми і шукати шляхи їх раціонального вирішення;

- використовувати сучасні технології виробництва;

- чітко усвідомлювати, де і яким чином придбані знання можуть бути застосовані в реальній дійсності;

- бути здатним генерувати нові ідеї;

- грамотно працювати з інформацією;

- вміти систематизувати факти, необхідні для вирішення певної проблеми, аналізувати їх, висувати гіпотези вирішення проблем, проводити необхідні узагальнення, зіставляючи 3 аналогічними або альтернативними варіантами вирішення;

- формулювати аргументовані висновки, застосовувати отримані результати для вирішення виникаючих проблем;

- розвивати комунікативну компетентність, важливу для діяльності в соціальних групах, професійних колективах;

- удосконалювати мотивацію, спрямовану на розвиток інтелектуального потенціалу.

Поставлені завдання вимагають інших, більш прогресивних підходів та прийомів до підготовки кваліфікованого кадрового забезпечення. Особливе значення в педагогічній теорії і практиці останнього десятиліття відводиться компетентнісному підходу як провідній стратегії підготовки фахівців нового покоління. Ця стратегія визначила важливість технології проектного навчання в процесі формування не тільки знань, умінь, навичок і особистісних якостей учнів закладів професійно-технічної освіти, а й спеціально-професійних компетентностей, необхідних їм як майбутнім фахівцям високого рівня.

Аналіз основних досліджень і публікацій. Теорія і практика реалізації проектної технології навчання неодноразово висвітлювались у дослідженнях вітчизняних та зарубіжних вчених: Дж. Дьюї, В. Кілпатріка, О. Коберника, М. Корця, В. Мадзігона, Н. Пахомової, О. Пєхоти, С. Полат, В. Сидоренка, С. Сисоєвої, В. Тименка, С. Шацького та інших.

Історію виникнення та становлення технології проектів у своїх працях робили спробу висвітлити I. Ворончіхіна, М. Елькін, М. Кнолл, Б. Назаренко, О. Огієнко, О. Пеньковських, В. Стернберг.

Окремі аспекти впровадження технології проектної діяльності у систему професійної підготовки кваліфікованих робітників описано у роботах Т. Герлянд, Р. Гуревича, М. Кадемії, Г. Романової.

Мета статті - проаналізувати етапи становлення та розвитку технології проектної діяльності у системі трудової та професійної підготовки підростаючого покоління.

Виклад основного матеріалу. На теренах вітчизняного та зарубіжного освітнього простору проектна технологія навчання у певних різновидах існує і використовується на практиці не один рік. Більшість вчених застосування проектнопроблемного навчання пов'язують 3 новаторськопросвітницькою діяльністю Дж. Дьюї та В. Кілпатрика. Проте технологія має довгу передісторію, яка сягає своїм корінням у XVI XVII століття [2].

Як зазначає німецький вчений М. Кнолл, виникнення феномену “проект” пов'язано зі спробами італійських архітекторів у XVI столітті професіоналізувати свою діяльність та заявити про архітектуру як про науку, зробивши її навчальною дисципліною. Відповідно до цього у Римській вищій школі мистецтв до лекційних занять було додано конкурс - можливість кращим студентам створити ескіз. Така діяльність давала можливість вихованцям розкривати творчі здібності та навики, проявляти індивідуальний професійний стиль. Згодом ескізи почали називатися проектами, зокрема під час розробки ескізів планів будівель [13].

Архітектурна європейська основа дала поштовх до застосування проектного навчання у професійній освіті робітничих шкіл, що стали виникати на німецькомовних землях у першій половині XVII століття. Одним із ідеологів робітничої школи був Джон Локк (1632 - 1704), англійський філософ, просвітитель і державний діяч. У Записці “Робітничі школи” (1696р.) до проектузакону про бідних Джон Локк звертається до проблеми соціального значення дитячої праці, де пропонує створювати у кожній общині навчально-виховні заклади, призначені для дітей 


\section{ДЕЯКІ АСПЕКТИСТАНОВЛЕННЯ ТАРОЗВИТКУ ПРОЕКТНОЇТЕХНОЛОГІЇНАВЧАННЯ У СИСТЕМІПРОФЕСІЙНОӤПІДГОТОВКИ КВАЛІФІКОВАНИХ РОБІТНИКІВ}

бідноти від 3 до 14 років, що стало своєрідним поєднанням дошкільних закладів і елементарних шкіл [6].

Поступово проектний спосіб навчання переходить з Європи до Америки. Як відзначає Л. Довгополова у 1879 році при Вашингтонському університеті у Сент-Луїсі була заснована школа ручного навчання (Manual Training School), де використовувався метод проектів. Учні повинні були не тільки розробляти проекти, але й виконувати їх реально в технічних майстернях, вони майстрували полиці, підсвічники, будували мотори. Учні самі відповідали за планування та реалізацію проекту, спираючись на реальні проблеми життя або професійної діяльності [2].

На початку XX століття проектне навчання набуває особливої популярності у США завдяки новим діяльнісним підходам до організації навчально-виробничого процесу. У цей час гостро постала проблема навчання дітей, які в силу своїх здібностей, інтересів, зайнятості не могли засвоїти необхідний навчальний мінімум, а отже - виникла необхідність у нових формах знань, оскільки потужний розвиток тогочасного американського виробництва потребував творчої, самостійної особистості, яка могла б швидко та ефективно застосувати свої знання на практиці $[8 ; 11]$.

Теоретичною основою проектної технології навчання стали ідеї американського педагога, психолога, соціолога та реформатора, представника філософії прагматизму Дж. Дьюї (1859 - 1952), хоча в своїх роботах він ніколи не використовував слова “проект". У книзі “Школа і суспільство” Дж. Дьюї писав: “3 точки зору дитини найбільший недолік школи походить від неможливості для неї вільно, у повній мірі використовувати досвід, набутий поза школою, в самій школі. I, навпаки, з іншого боку дитина виявляється нездатною застосувати в повсякденному житті те, чому навчилася у школі" [12]. Грунтовною перевагою проектної технології Дж.Дьюї вважав навчання на діяльнісній основі, що максимально відповідало інтересам, здібностям та потребам учня.

Вирішальне значення для розвитку ідеї проектів мав сформульований Д. Дьюї головний принцип навчання - “навчання через дію”, за яким сутністю процесу навчання є відкриття, тобто постійне, реальне втілення чогось нового. Саме дія стала основою розробленого вченим "методу проблем" [7, 34].

Послідовником ідей Дж. Дьюї був професор педагогіки учительського коледжу при Колумбійському університеті Вільям Херд Кілпатрик (1871 - 1965), який вважав надзвичайно важливим показати дітям їх особисту зацікавленість у придбаних знаннях, які можуть $і$ повинні знадобитися їм у житті.

У своїй грунтовній праці "Метод проектів" В. Кілпатрик запропонував першу класифікацію проектів відповідно до мети, характеризуючи метод проектів як метод планування доцільної діяльності у зв'язку з вирішенням певного навчального завдання у реальній життєвій ситуації, як діяльність, яка “виконується від щирого серця", з високим рівнем самостійності та зацікавленості учнів. "Уявіть собі дівчину, яка пошила собі сукню, - писав В. Кілпатрик. - Якщо вона вклала душу в свою роботу, працювала охоче, 3 любов'ю, самостійно зробила викрійку і придумала фасон сукні, самостійно його пошила, то це і $є$ зразок типового проекту, у власне педагогічному сенсі цього слова" [3].

В. Кілпатрик обгрунтував не тільки переваги, а й недоліки проектної технології навчання. Він доводив, що недолік проектного навчання полягає у тому, що його не завжди можна використати у освітньому процесі, оскільки не в кожної дитини вдається розвинути осмислену цілеспрямованість діяльності. Через це вчений не вважав за потрібне у навчальному процесі обмежуватися тільки проектною технологією [14].

Згодом метод проектного навчання поширився і на інші країни. Так, наприклад, на теренах російської педагогіки найближче до технології проектів у своїй діяльності підійшов С. Шацький 3 ідеями організації трудової діяльності учнів без відриву від навчальної. Він використовував американські напрацювання у сфері проектного навчання і адаптував їх до специфіки радянської школи [8, 311]. “А цій справі, - зазначав С. Шацький, - треба вчитися не на словах, а через практичну діяльність, в якій повинна бути чітко визначена лінія: задум - план осмислення процес - результат - аналіз" [10].

Історія вітчизняного проектного навчання, на думку багатьох дослідників, починається 3 педагогічної діяльності А. Макаренка (1888 1939). Система роботи видатного педагога була зорієнтована на прилучення молоді до найбільш передових галузей виробництва як засіб професіоналізації і водночас формування особистості нового покоління.

Багато в чому перегукуючись 3 алгоритмом та сучасними підходами до організації проектного навчання, система діяльності А. Макаренка дозволяла активізувати особистість та забезпечити її різнобічний розвиток, надзвичайно важливий для майбутнього фахівця, що також свідчить про необхідність раннього “входження" 


\section{ДЕЯКІ АСПЕКТИСТАНОВЛЕННЯТАРОЗВИТКУ ПРОЕКТНОӤТЕХНОЛОГІЇНАВЧАННЯ У СИСТЕМІПРОФЕСІЙНОӤПДГОТОВКИКВАЛФІКОВАНИХ РОБІТНИКІВ}

в професійну сферу. Педагогічні проекти, що на сьогодні виокремлюються дослідниками педагогічного доробку А. Макаренка, усували проблематику засвоєння учнями теоретичного матеріалу, сприяли практичному оволодінню уміннями та формуванню навичок, підвищували соціально зорієнтований багатосторонній розвиток суб'єкта навчання $[1,60]$.

Як відзначає О. Купенко, у педагогічнопроектній діяльності А. Макаренко виокремлював близьку, середню та віддалену перспективи. Близька перспектива базується на особистісній зацікавленості групи осіб, які навчаються, може реалізовуватися навіть унайбільш непідготовлених групах. Головне, що кожен має сприймати запропоноване як власну радість завтрашнього дня, передчувати задоволення.

Середня перспектива за А. Макаренком - це проект колективної події, дещо віддаленої в часі. Щоб досягнути цієї перспективи, потрібно докласти зусиль.

Віддалена перспектива - це перспектива, що не лише віддалена у часі й потребує значних спільних зусиль, але й така, в якій узгоджуються особистісні та суспільні потреби. Як показала практика А. Макаренка та його однодумців, створення таких перспективних ліній дозволяє досягти істотних результатів як у навчанні, так i в вихованні. Однак проекти ці мають бути не “іграшковими”, а відповідати реальним потребам навколишнього середовища $[5,46]$.

Практичним продовжувачем проектних ідей А. Макаренка був відомий педагог-новатор 3 Черкащини О. Захаренко (1937 - 2002). У своїй книзі “Школа над Россю" О. Захаренко стверджував, що у формуванні особистості важливу роль відіграють постійне оновлення та примноження духовних багатств школи, до яких він відносив ідейні, громадські, естетичні, трудові та моральні цінності колективу. Шляхи примноження духовних багатств він вбачав у вдосконаленні наявних та створенні нових духовних цінностей. Пояснюючи технологію цього процесу, педагог звертав увагу на особливості моделювання виховних заходів, сутність якого полягала в тому, що певні періоди життя шкільного колективу мали окреслену виховну спрямованість і завершувалися заходом (чи заходами) великого педагогічного ефекту (кінцевий результат) [4, 189].

О. Захаренко був одним із фундаторів педагогіки співробітництва - системи форм, методів і засобів у навчально-виховному процесі, які спираються на принципи гуманізмуі творчого підходу до розвитку особистості дитини. Як і всі інші педагоги-новатори, він висунув, обгрунтував і впровадив у педагогічну практику ідеї, що сьогодні покладені в основу проектної технології навчання: творчої взаємодії педагога і учня, навчання без примусу, досягнення поставленої мети шляхом індивідуального і колективного підходу до діяльності учнів, творчого самоврядування, особистісно-орієнтованого підходу до виховання та навчання учнів, співпраці з батьками, громадськістю тощо $[9,5]$.

За останні роки технологія проектів зміцнила свої позиції на теренах вітчизняного освітнього простору. Науковцями та педагогами-практиками здійснено колосальну роботу з теоретичних обгрунтувань технології, способів та засобів їі практичного впровадження в освітній процес на всіх рівнях, опису та обгрунтування етапів проектної діяльності, типології проектів, ролі педагога та учня в організації проектного навчання тощо (Л. Ващенко, В. Гузєєва, О. Коберник, М. Корець, Н. Пахомова, О. Пєхота, В. Сидоренко, А. Терещук, В. Тименко, С. Ящук та інші).

Варто відзначити, що більшість сучасних досліджень технології проектного навчання стосується іiі впровадження у систему загальної та вищої освіти, і майже недослідженою залишається в цьому плані професійно-технічна ланка.

Висновки. Сучасний етап розвитку вітчизняної професійної освіти диктує свої вимоги та підходи до ії організації. Помітне місце в цьому процесі займає впровадження проектної технології навчання. Для педагогів-практиків це гарна нагода відійти від знаннєво-теоретичної освітньої основи та наблизитись до прагматично-діяльнісного, особистісно-зарієнтованого підходів у навчанні. Раціонально організована проектна діяльність учнів професійно-технічних закладів освіти дає їм змогу самостійно здобувати знання та застосовувати їх на практиці.

Безперечно, використання технології проектного навчання у системі професійної підготовки кваліфікованих робітників сьогодні має надзвичайні перспективи, адже проектування поступово перетворюється на інтелектуальну діяльність людини в усіх сферах: соціальноосвітній, виробничій, культурній, науковій, економічній, технічній тощо. Це сприяє розвитку та становленню особистості учня як суб'єкта діяльності та соціальних відносин.

\section{ЛIТЕРАТУРА}

1. Борисенко Д. Педагогічні ідеї А.С. Макаренка через призму інформаційно-комунікативних освітніх інновацій сучасної вищої школи / Д. Борисенко // Витоки педагогічної майстерності. -2014. - Випуск 13. -C. $59-63$. 


\section{ДЕЯКІ АСПЕКТИСТАНОВЛЕННЯТА РОЗВИТКУ ПРОЕКТНОӤ ТЕХНОЛОГІЇ НАВЧАННЯ У СИСТЕМІПРОФЕСІЙНОӤ ПДГОТОВКИ КВАЛІФІКОВАНИХ РОБІТНИКІВ}

2. Довгополова Л. Д. Метод проектів у зарубіжній педагогічній теорії та практиці: історичний аспект / Л.Д.Довгополова // Вісник Національного авіаційного університету. Педагогіка. Психологія. - К., 2015. - Вип. $1(6) .-$ C. $81-87$.

3. Килпатрик В. Х. Метод проектов. Применение целевой установки в педагогическом процессе / В. Х. Кильпатрик; [пер. с англ. Е. Н. Янжул]. - Л.: Брокгауз-Ефрон, 1925. - 43 с.

4. Крутенко О. Розвиток ідей А.С. Макаренка у педагогічній спадщині О.А. Захаренка / О. Крутенко // Витоки педагогічної майстерності. - 2013. - Випуск 11. -C. $187-192$.

5. Купенко О. В. Педагогічні проекти: навчальний посібник / О.В. Купенко. - Суми: Сумський державний університет, 2015. $-133 \mathrm{c}$.

6. Локк Д. Мысли о воспитании // Хрестоматия по истории зарубежной педагогики. - М.: Просвещение, 1981.-C. $163-194$.

7. Огієнко О. Тенденції розвитку проектної технології у зарубіжній педагогіці XX століття / О. Огієнко // Порівняльна професійна педагогіка. - 2011. - № 1. C. $31-38$.

8. Пеньковских Е. А. Метод проектов в отечественной и зарубежной педагогической теории и практике Е. А. Пеньковских // Вопросы образования. - 2010. №4. - C. 307-318.

9. Черевко О.В. Реалізація ідей гуманної педагогіки Олександра Захаренка в досвіді авторської “Школи над Россю" / О.В. Черевко // Вісник Черкаського університету. -2017. - Вип. № 1. - С. $4-10$.

10. Шацкий С. Т. Избранные педагогические сочинения: В 2 т. [Текст] / С. Т. Шацкий. - М., 1980. T. $1 .-304 \mathrm{c}$.

11. Шелудько I. Досвід використання методу проектів на уроках “технологій” у загальноосвітніх навчальних закладах США / І. Шелудько // Порівняльна професійна педагогіка. - 2015. - № 3. - С. 99-104.

12. Dewey J. Experience in Education. The latter works of J. Dewey // Carbondale: Southern Illinois University Press. - 1938. - Vol.13. -64 p.

13. Knoll M. Europa nicht Amerika. Zum Urschprung der Projektmethode in der Paedagogik 1702-1875// Paedagogiche Rundschau. - 45 (1991). - S. 41 - 58.

14. Marginson S. Global field and global imagining: Bourdieu and worldwide higher education / S. Marginson // British Journal of Sociology of Education. - May 2008. - Vol. 29. - No. 3. - P. 303-315.

\section{REFERENCES}

1. Borysenko, D. (2014). Pedahohichni ideyi A.S. Makarenka cherez pryzmu informatsiynokomunikatyvnykh osvitnikh innovatsiy suchasnoyi vyshchoyi shkoly [Pedagogical Ideas AS Makarenko through the prism of informational and communicative educational innovations of modern high school]. Origins of pedagogical skill, Issue 13, pp. 59-63. [in Ukrainian].

2. Dovgopolova, L. D. (2015). Metod proektiv u zarubizhniy pedahohichniy teoriyi ta praktytsi: istorychnyy aspekt [Method of projects in foreign pedagogical theory and practice: historical aspect] Bulletin of the National Aviation University. Pedagogy. Psychology, Issue 1 (6), pp. 81-87. [in Ukrainian].

3. Kilpatrick, V. H. (1925). Metod proyektov. Primeneniye tselevoy ustanovki $v$ pedagogicheskom protsesse [Method of projects. Application of the target setting in the pedagogical process]. Leningrad: BrockhausEfron, 43 p. [in Russian].

4. Krutenko, O. (2013). Rozvytok idey A.S. Makarenka u pedahohichniy spadshchyni O.A. Zakharenka [Development of ideas of A.S. Makarenko in the pedagogical heritage of O.A. Zaharenko]. Origins of pedagogical skill, Issue 11,pp. 187 - 192. [in Ukrainian]

5. Kupenko, O. V. (2015). Pedahohichni proekty [Pedagogical projects]. Sumy: Sumy State University, 133 p. [in Ukrainian].

6. Locke, D. (1981). Mysli o vospitanii [Thoughts on education]. Moscow: Education, pp. 163 - 194. [in Russian].

7. Ogienko, O. (2011). Tendentsiyi rozvytku proektnoyi tekhnolohiyi u zarubizhniy pedahohitsi XX stolittya [Trends in the development of project technology in foreign pedagogy of the twentieth century]. Comparative professional pedagogy, no. 1, pp. 31 - 38. [in Ukrainian].

8. Penkovskikh, Ye. (2010). Metod proyektov $v$ otechestvennoy $i$ zarubezhnoy pedagogicheskoy teorii $i$ praktike [The method of projects in domestic and foreign pedagogical theory and practice]. Questions of education, no. 4, pp. 307-318. [in Russian].

9. Cherevko, O.V. (2017). Realizatsiya idey humannoyi pedahohiky Oleksandra Zakharenka $v$ dosvidi avtorskoyi "Shkoly nad Rossyu" [Realization of humanistic pedagogy of Olexandr Zakharenko in the author's "Schools over Rossyu"]. Bulletin of Cherkasy University, no. 1, pp. 4-10. [in Ukrainian]

10. Shatsky, S. T. (1980). Izbrannyye pedagogicheskiye sochineniya: $v 2 t$. [Selected Pedagogical Compositions: in 2 vol.]. Moscow, vol. 1, 304 p. [in Russian].

11. Sheludko, I. (2015). Dosvid vykorystannya metodu proektiv na urokakh "tekhnolohiy" u zahalnoosvitnikh navchalnykh zakladakh SSHA [Experience of using the method of projects at the lessons of "technologies" in general education institutions of the USA]. Comparative professional pedagogy, no. 3, pp. 99 - 104. [in Ukrainian].

12. Dewey, J. (1938). Experience in Education. The latter works of J. Dewey. Carbondale: Southern Illinois University Press, vol.13, 64 p. [in English].

13. Knoll, M. (1991). Europa nicht Amerika. Zum Urschprung der Projektmethode in der Paedagogik 1702-1875 [Europe is not America. On the origin of the project method in paedagogics 1702-1875]. Paedagogiche Rundschau, no. 45, pp. 41 - 58. [in German].

14. Marginson, S. (2008). Global field and global imagining: Bourdieu and worldwide higher education. British Journal of Sociology of Education, vol. 29, no. 3, pp. 303 - 315. [in English]

Стаття надійшла до редакції 21.06.2018 